\title{
RECONNAISSANCE REPORT ON THE WEBER EARTHQUAKE - 13 MAY 1990
}

\author{
P. G. Johnstone ${ }^{1}$ and R. Potangaroa ${ }^{2}$ \\ (edited by P. J. Moss ${ }^{3}$ )
}

\begin{abstract}
SUMMARY
On 13 May 1990, an earthquake of magnitude 6.7 occurred near Dannevirke and caused damage both there and in the surrounding area.

This report presents the observations of a two person reconnaissance team from the New Zealand National Society for Earthquake Engineering together with details provided by the Engineering Seismology Section of the Institute of Geological and Nuclear Sciences (formerly part of the DSIR).
\end{abstract}

\section{INTRODUCTION}

The Weber earthquake, centred near Motea, a rural district some $20 \mathrm{~km}$ south east from Dannevirke occurred at $4.23 \mathrm{pm}$ on Sunday 13 May 1990. It generated damaging intensities of shaking in and around Dannevirke but no event in its aftershock sequence is reported to have caused damage. A less damaging earthquake, of similar magnitude to the Weber main shock, had occurred in the district on 19 February 1990.

At the time, DSIR seismologists thought the peak ground accelerations were probably in the order of $0.5 \mathrm{~g}$ in Dannevirke, and that the predominant frequencies were in the $2 \mathrm{~Hz}$ range ( 0.5 second period).

On the day after the earthquake, a two person reconnaissance team comprising Peter Johnstone, structural engineer, and Regan Potangaroa, structural engineer, was sent from the New Zealand National Society for Earthquake Engineering to inspect damage in Dannevirke and the surrounding area.

This report is based on observations made during the two days following the earthquake and discussions with local residents, officers of the Tararua District Council, as well as other engineers who came to inspect the damage. It also includes later information about the strong motion records obtained from the earthquake contributed by the Engineering Seismology Section of the Institute of Geological and Nuclear Sciences (formerly part of the DSIR).

Various interesting observations were made during and after the earthquake, some by local inhabitants, including:

1 Holmes Consulting Group Ltd, Wellington (Member)

2 Truebridge, Callendar and Beach SDN BHD, Brunei.

3 University of Canterbury, Christchurch (Fellow and Bulletin Editor) (a) At Weber, power poles were reported to be oscillating through a $30^{\circ}$ arc (i.e. $\pm 15^{\circ}$ from vertical).

(b) The local Traffic Officer saw 'waves' of motion coming towards him while he was driving down a straight road.

(c) Golfers on the Dannevirke course reported seeing ground surface waves.

(d) A concrete water tank, some $2.4 \mathrm{~m}$ in diameter and $3.0 \mathrm{~m}$ high, sitting directly on the ground at Motea, moved approximately $150 \mathrm{~mm}$ to the north west. There was no sign of reversals of movement.

(e) At the Bank of New Zealand in Dannevirke, a steel safe, roughly $600 \mathrm{~mm}$ cube, was sitting on a raised wooden platform. The safe had moved towards the north west by $40 \mathrm{~mm}$, approximately at right angles to the main road outside.

(f) Mr Tony Small, a jeweller, suggested that the earthquake had a direction at right angles to the main street.

(g) In the Dannevirke Electrical Appliance Store attendants said that the damage was not as bad as the February earthquake in terms of damage to stock. There was no damage to the building on the outside and even some high stands with three levels of microwave ovens on them did not topple.

(h) In an upper level storeroom of the BNZ building, one metal bookcase had been distorted in a north-west direction. This is consistent with the strong motion of the earthquake being at right angles to the main street.

(i) The majority of the buildings in the town survived better than one might have expected. However, the majority of the buildings in the town have party or long boundary walls running at right angles to the 


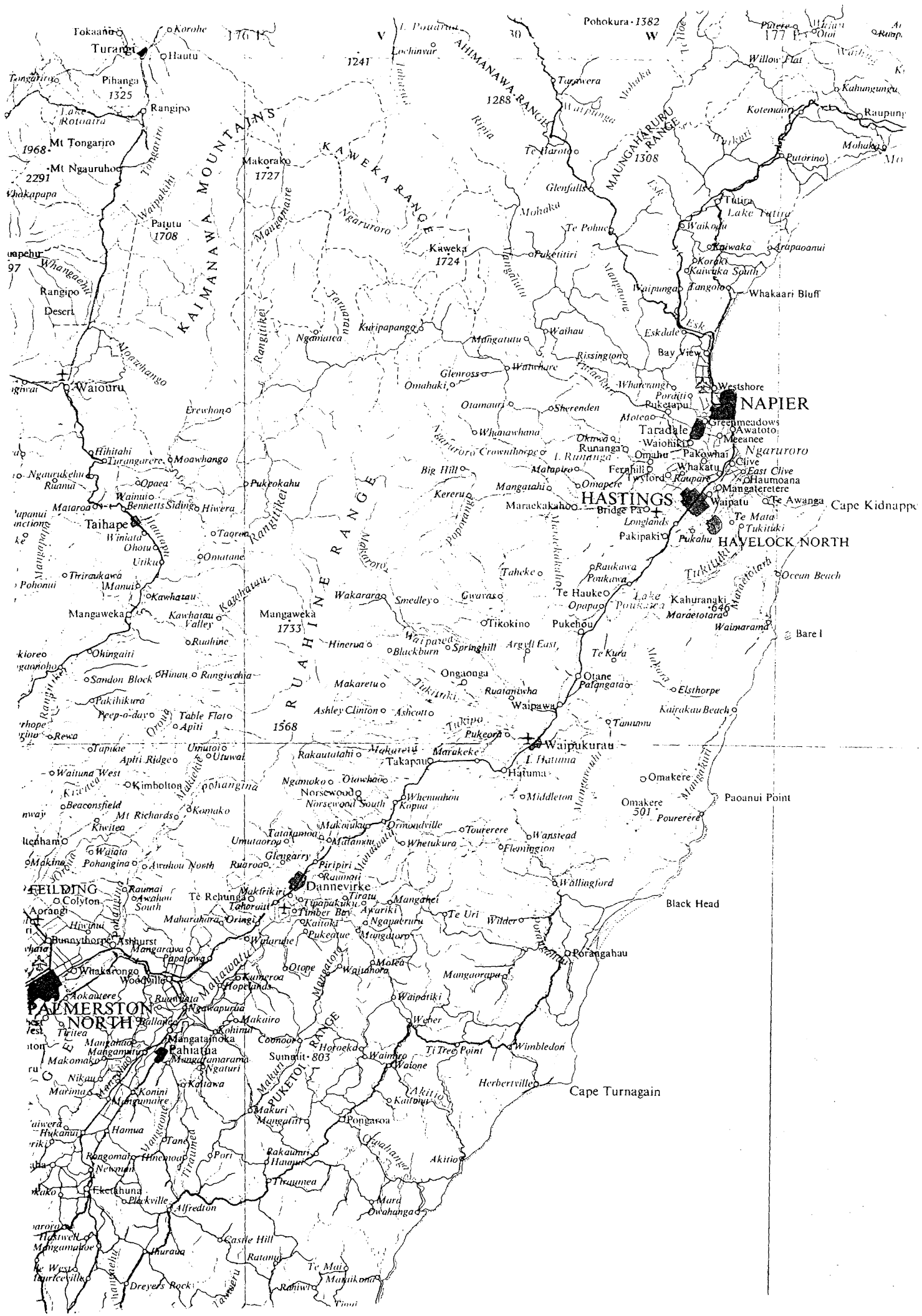

Figure 1 Map of the general area showing Dannevirke and the affected region to the south of Dannevirke. 


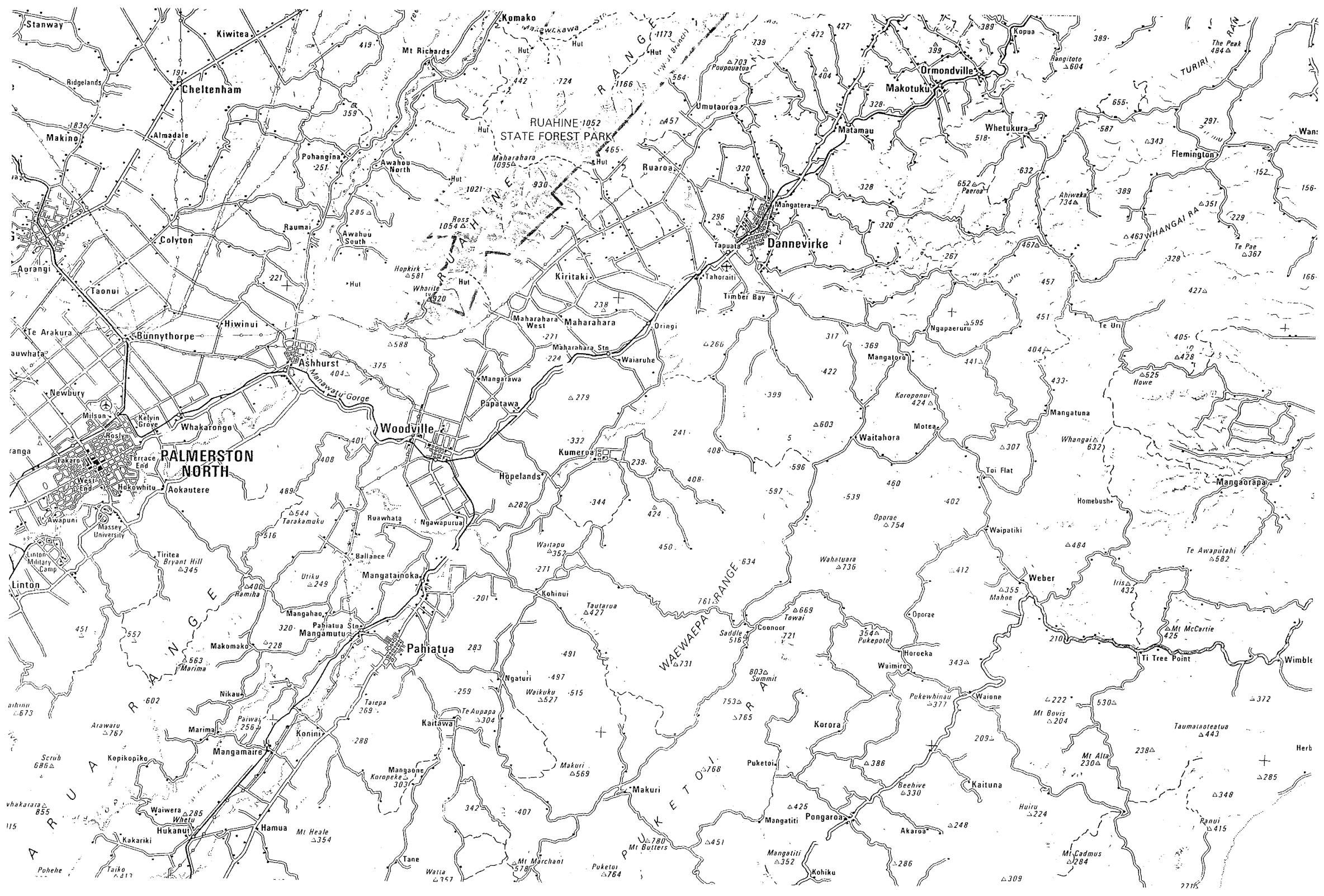

Figure 2 Detailed map of the area 
street and therefore in the same direction as the earthquake's perceived major acceleration. This would give enhanced strength.

These observations suggest a strong north west - south east jolt was the principal destructive component of the earthquake; but parapet damage attributable to north east south west acceleration was also significant. When interpreting the more dramatic accounts of transient phenomena the possibility should not be overlooked of observer fallibility due to human reaction to such an unfamiliar and awesome event as strong ground shaking.

\section{GEOGRAPHY OF THE AREA}

The Dannevirke area (see Figure 1) is bounded on the western side by the Ruahine Ranges, which start at the Manawatu Gorge. A broad valley runs from Pahiatua on towards Napier in the north east and there is one significant range called the Puketoi Range running parallel to the Ruahine Range and the coast and roughly midway between them. The Puketoi Range runs just to the east of Makuri and reduces in altitude towards Motea which is near the epicentre of the earthquake.

The region has generally rolling but quite steep faced hills, is generally fairly stable in terms of land slippage except for some zones of bentonite/mudstone, and any slippage is normally shallow seated. Apart from the Puketoi Range, the area is all grassland pastoral farming and is reasonably sparsely populated. The roading pattern is widely spaced with many secondary roads being unsealed.

\section{EARTHQUAKE DESCRIPTION}

\section{Seismicity}

Initial assessments of the epicentre placed it near Dannevirke with later more detailed analyses placing it at Motea, some $20 \mathrm{~km}$ southeast of Dannevirke (see Figure 2).

A number of people reported feeling the earthquake as a rolling motion while others reported the motion as being predominantly a jolting one.

\section{Strong Motion Records}

The Weber earthquake of 13 May 1990 produced one of the largest sets of acceleration records obtained for a New Zealand earthquake [1]. A similar set of records was obtained from the earlier event of 19 February 1990 [2]. Peak accelerations for the two events are tabulated in Table 1 for sites within $150 \mathrm{~km}$ of the epicentre. Table 2 lists peak accelerations from sites in Lower Hutt and Wellington. The values given are the peak accelerations in any horizontal direction. The distances are for epicentres of $40.36^{\circ} \mathrm{S}$ and $176.36^{\circ} \mathrm{E}$ for the February event and $40.28^{\circ} \mathrm{S}$ and $176.30^{\circ} \mathrm{E}$ for the May event, and update the distances listed in the data reports [1] and [2].

An attenuation curve for these peak ground accelerations given by Dowrick and Sritharan $[3,4]$ lies above the mean plus standard deviation curve of Joyner and Boore's model [5] for distances up to slightly more than $70 \mathrm{~km}$ from the source, and above the mean Joyner and Boore curve across the whole distance range of the data. The greater strength of the peak ground accelerations from the Weber earthquake compared to those predicted by models based principally on Western United States data, was typical for the eight shallow New Zealand earthquakes studied in detail by Dowrick and Sritharan.

The record closest to the source of the 13 May earthquake was obtained from the Dannevirke Post Office at an epicentral distance of $19 \mathrm{~km}$, with a peak horizontal acceleration of $0.39 \mathrm{~g}$. The acceleration, velocity and displacement histories of the N67E component are shown in Figure 3. The 5\% damped acceleration response spectrum of this component peaked at $11200 \mathrm{~mm} / \mathrm{s}^{2}$ at 0.13 seconds period, with another strong peak of $9130 \mathrm{~mm} / \mathrm{s}^{2}$ at 0.6 seconds. The spectrum is compared with the El Centro 1940 north-south component in Figure 4. The strongest peak of the S23E component was $10300 \mathrm{~mm} / \mathrm{s}^{2}$ at 0.22 seconds period. This record supersedes the Matahina dam base record from the 1987 Edgecumbe earthquake as the strongest ground acceleration record yet obtained in New Zealand, although a scratch-plate acceleroscope record gave a peak ground acceleration of $0.61 \mathrm{~g}$ at a shortest distance of about $15 \mathrm{~km}$ from the fault rupture in the Ms 7.4 Inangahua earthquake [6].

\section{DAMAGE IN RURAL AREAS}

No damage was observed on the road from Pahiatua (see Figure 2) until after passing through Makuri and climbing the Puketoi Range heading towards Pongaroa. On the section of road between Makuri and the summit, a number of cracks were found at the inside edge of the bends in the road, where there had been fill obviously placed in the past when the road was constructed. Cracks had opened up where the fill had slumped slightly, and in many cases, they were obviously older cracks which had moved in the past due to slumping during heavy rain. Patching in the seal was evident.

This cracking probably accounted for $50 \%$ of the road damage, with movement occurring along old slump planes. In no place was the road impassable to normal traffic, although road gangs had been filling up the worst of the gaps with sand to help smooth the road surface.

Similarly, some cut banks above the road had slumped, but this was usually the surface ravelling with no deep seated movements. In no case was more than a quarter of the total road width covered by such slumping. However, one could anticipate further problems after heavy rain, because there were probably cracks in the ground above such slumps. Any water pressurising and lubricating such cracks could cause more deep seated movement.

From the summit of the Puketoi Range to Pongaroa, the damage to the roads was noticeably less severe, and there was no sign of any large scale movements in the surrounding area visible from the car. This was intriguing because this was nearer the epicentre, yet the damage was less.

From Pongaroa to Weber, the road follows a river valley and passes through Waione. There was one bridge near Waione on that route (Highway 52) which showed some minor slumping at the abutments and some distress to the piers. However, a team from Works Consultancy checked the 
Table 1: Peak accelerations from the Weber earthquakes of 19th February and 13th May 1990 for sites less than $150 \mathrm{~km}$ from the epicentre. Sites are listed in order of increasing epicentral distance for the 13th May event. Note that scratch-plate sites do not have site numbers.

\begin{tabular}{|c|c|c|c|c|c|c|}
\hline $\begin{array}{l}\text { SITE } \\
\text { NO. }\end{array}$ & SITE NAME & $\begin{array}{c}\text { INSTRUMENT } \\
\text { TYPE }\end{array}$ & $\begin{array}{c}\text { EPICENTRAL } \\
\text { DISTANCE } \\
(\mathbf{k m})\end{array}$ & $\begin{array}{c}\text { PEAK } \\
\text { ACCELERATION } \\
(\mathrm{g})\end{array}$ & $\begin{array}{c}\text { EPICENTRAL } \\
\text { DISTANCE } \\
(\mathrm{km})\end{array}$ & $\begin{array}{c}\text { PEAK } \\
\text { ACCELERATION } \\
\text { (g) }\end{array}$ \\
\hline & & & \multicolumn{2}{|c|}{19 February 1990} & \multicolumn{2}{|c|}{13 May 1990} \\
\hline \multirow[t]{2}{*}{$033 \mathrm{C}$} & Dannevirke Post Office & film & 28 & $\star \star \star \star \star ~$ & 19 & .390 \\
\hline & Dannevirke Post Office & $\mathrm{sp}$ & 28 & 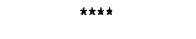 & 19 & .39 \\
\hline \multirow[t]{2}{*}{ 033A } & Dannevirke Telephone Exchange & film & 28 & .295 & 19 & $\star \star \star \star ~$ \\
\hline & Dannevirke Telephone Exchange & $s p$ & 28 & .34 & 19 & $\star \star \star \star$ \\
\hline \multirow[t]{2}{*}{$120 \mathrm{~A}$} & Woodville Post Office & film & 42 & .238 & 37 & .165 \\
\hline & Pahiatua & $s p$ & 45 & .13 & 43 & .17 \\
\hline \multirow[t]{3}{*}{$032 \mathrm{~A}$} & Waipawa Post Office & film & 51 & .202 & 46 & .245 \\
\hline & Waipawa Post Office & $\mathrm{sp}$ & 51 & .24 & 46 & .29 \\
\hline & Castlepoint & $\mathrm{sp}$ & 61 & .09 & 69 & .10 \\
\hline $340 \mathrm{~A}$ & Massey University (Tunnel) & film & 63 & .056 & 59 & .056 \\
\hline $340 \mathrm{~B}$ & Massey University (Ground) & film & 63 & .064 & 59 & .064 \\
\hline $340 \mathrm{C}$ & Massey University (4th floor) & film & 63 & .100 & 59 & .093 \\
\hline $340 D$ & Massey University (8th floor) & film & 63 & .116 & 59 & .178 \\
\hline \multirow[t]{2}{*}{$301 \mathrm{~A}$} & Palmerston North Telephone Exch. & film & 63 & .046 & 59 & .037 \\
\hline & Palmerston North Telephone Exch. & $s p$ & 63 & .05 & 59 & .05 \\
\hline O39D & Masterton Telephone Exchange & film & 88 & $\star \star$ & 92 & .028 \\
\hline \multirow[t]{2}{*}{ O39E } & Masterton Telephone Exchange & dig. & 88 & .018 & 92 & .030 \\
\hline & Masterton Telephone Exchange & sp & 88 & .02 & 92 & .03 \\
\hline $110 \mathrm{C}$ & South Rangitikei Rail (Remote) & film & 78 & .029 & 68 & $\mathrm{nr}$ \\
\hline 029A & Hastings Civil Defence $\mathrm{Hq}$. & dig. & 89 & .044 & 84 & .060 \\
\hline \multirow[t]{3}{*}{$114 A$} & Ohakea RNZAF Signal Station & film & 85 & .035 & 79 & .039 \\
\hline & Taihape Post Office & $s p$ & 90 & $*$ & 80 & $.09^{\star}$ \\
\hline & Levin Telephone Exchange & sp & 95 & * & 93 & $.06^{*}$ \\
\hline \multirow[t]{2}{*}{ 027D } & Napier Museum & film & 108 & $\mathrm{nr}$ & 103 & $\mathrm{nr}$ \\
\hline & Napier Museum & $s p$ & 108 & .03 & 103 & $\mathrm{nr}$ \\
\hline \multirow[t]{2}{*}{$116 \mathrm{~A}$} & Otaki, Chatterton Motors & film & 112 & $\mathrm{nr}$ & 112 & $\mathrm{nr}$ \\
\hline & Otaki, Chatterton Motors & $s p$ & 112 & * & 112 & $.04^{*}$ \\
\hline \multirow[t]{2}{*}{ 098A } & Martinborough Post Office & film & 122 & $\mathrm{nr}$ & 126 & $\mathrm{nr}$ \\
\hline & Martinborough Post Office & $\mathrm{sp}$ & 122 & .03 & 126 & .02 \\
\hline $200 \mathrm{~A}$ & Moawhango Dam & film & 118 & $\mathrm{nr}$ & 108 & $\mathrm{nr}$ \\
\hline $102 \mathrm{~A}$ & Karioi Pulp Mill & film & 120 & .046 & 110 & .049 \\
\hline \multirow[t]{3}{*}{$302 A$} & Wanganui Post Office & dig. & 121 & .028 & 113 & .065 \\
\hline & Wanganui Post Office & $\mathrm{sp}$ & 121 & .02 & 113 & .07 \\
\hline & Paraparaumu Telephone Exchange & $\mathrm{sp}$ & 130 & * & 130 & $.04^{*}$ \\
\hline $123 \mathrm{~A}$ & Te Marua Dam (Remote) & film & 131 & $\mathrm{nr}$ & 133 & $.013^{\star \star \star}$ \\
\hline $087 \mathrm{~A}$ & Atene (Puketapu) & film & 126 & .063 & 117 & .091 \\
\hline 087B & Atene (midway Puketapu) & film & 127 & $\mathrm{nr}$ & 117 & $\mathrm{nr}$ \\
\hline \multirow[t]{2}{*}{$087 \mathrm{C}$} & Atene (valley) & film & 127 & .081 & 117 & .126 \\
\hline & Ohakune Telephone Exchange & $\mathrm{sp}$ & 133 & * & 123 & $.03^{\star}$ \\
\hline $643 \mathrm{~A}$ & Haywards Substation NZED & film & 146 & $\mathrm{nr}$ & 148 & $n r$ \\
\hline
\end{tabular}

\footnotetext{
film film recording accelerograph

dig. digital accelerograph

sp scratch-plate acceleroscope

nr no record

* $\quad$ site not visited between Weber events of 19/2/90 and 13/5/90

* faulty instrument, record corrupted, or late triggering

*** component peak only, record too small to digitize

$\star \star \star \star \quad$ accelerograph not installed.
} 
Table 2: Peak accelerations from sites in Lower Hutt and Wellington for the Weber earthquakes of 19th February and 13th May 1990. Sites are listed in order of increasing epicentral distance for the 13th May event. Note that scratchplate sites do not have site numbers.

\begin{tabular}{|c|c|c|c|c|c|c|}
\hline $\begin{array}{l}\text { SITE } \\
\text { NO. }\end{array}$ & SITE NAME & $\begin{array}{c}\text { INSTRUMENT } \\
\text { TYPE }\end{array}$ & $\begin{array}{l}\text { EPICENTRAL } \\
\text { DISTANCE } \\
(\mathrm{km})\end{array}$ & $\begin{array}{c}\text { PEAK } \\
\text { ACCELERATION } \\
\text { (g) }\end{array}$ & $\begin{array}{c}\text { EPICENTRAL } \\
\text { DISTANCE } \\
(\mathrm{km})\end{array}$ & $\begin{array}{c}\text { PEAK } \\
\text { ACCELERATION } \\
\text { (g) }\end{array}$ \\
\hline & & & \multicolumn{2}{|c|}{19 February 1990} & \multicolumn{2}{|c|}{13 May 1990} \\
\hline & Lower Hutt Sites .... & & & & & \\
\hline $\begin{array}{l}602 \mathrm{~A} \\
605 \mathrm{~A}\end{array}$ & Belmont Substation NZED & film & 152 & $\mathrm{nr}$ & 154 & $\mathrm{nr}$ \\
\hline $935 \mathrm{~A}$ & $\begin{array}{l}\text { Naenae Reservolr } \\
\text { Geological Survey, Lower Hutt }\end{array}$ & film & $\begin{array}{l}151 \\
155\end{array}$ & $\begin{array}{c}\mathrm{nr} \\
.012\end{array}$ & $\begin{array}{l}153 \\
155\end{array}$ & $n$ \\
\hline $935 \mathrm{~A}$ & Geological Survey, Lower Hutt & film & 155 & $\mathrm{nr}$ & 155 & $n r$ \\
\hline $606 \mathrm{~B}$ & Institute of Nuclear Sciences & dig. & 155 & .005 & 157 & .007 \\
\hline $606 \mathrm{~A}$ & Institute of Nuclear Sciences & film & 155 & $\mathrm{nr}$ & 157 & $\mathrm{nr}$ \\
\hline $642 \mathrm{C}$ & Physics and Engineering Lab & dig. & 156 & .015 & 158 & .024 \\
\hline $642 D$ & Physics and Engineering Lab & film & 156 & $\mathrm{nr}$ & 158 & $\mathrm{nr}$ \\
\hline & Physics and Engineering Lab & $s p$ & 156 & $\mathrm{nr}$ & 158 & .03 \\
\hline $604 \mathrm{~A}$ & Elizabeth Street Pumping Station & film & 156 & $\mathrm{nr}$ & 158 & $\mathrm{nr}$ \\
\hline $934 \mathrm{~A}$ & Shell Depot, Lower Hutt & film & 157 & $\mathrm{nr}$ & 159 & $\mathrm{nr}$ \\
\hline $936 \mathrm{~A}$ & Unilever, Lower Hutt & film & 157 & $\mathrm{nr}$ & 159 & $\mathrm{nr}$ \\
\hline $608 \mathrm{~A}$ & Petone Municipal building & film & 157 & $\mathrm{nr}$ & 159 & $\mathrm{nr}$ \\
\hline $603 \mathrm{~A}$ & Woollen Mills Substation & film & 159 & $\mathrm{nr}$ & 161 & $\mathrm{nr}$ \\
\hline & Wellington Sites .... & & & & & \\
\hline $924 \mathrm{~A}$ & William Clayton Building & film & 168 & $\mathrm{nr}$ & 170 & $\mathrm{nr}$ \\
\hline $902 \mathrm{~A}$ & Vogel Building & film & 168 & $\mathrm{nr}$ & 170 & $\mathrm{nr}$ \\
\hline $937 \mathrm{~A}$ & Pottery Assn. Wellington & film & 168 & $\mathrm{nr}$ & 170 & $\mathrm{nr}$ \\
\hline $922 \mathrm{~A}$ & Beehive & film & 168 & $\mathrm{nr}$ & 170 & $\mathrm{nr}$ \\
\hline $906 \mathrm{~A}$ & Reserve Bank (basement) & film & 168 & $.004^{\star \star \star}$ & 170 & $.011^{\star \star \star}$ \\
\hline $906 \mathrm{~B}$ & Reserve Bank (5th floor) & film & 168 & $.008^{\star \star \star}$ & 170 & $.022^{\star \star \star}$ \\
\hline $906 \mathrm{C}$ & Reserve Bank (14th floor) & film & 168 & $.010^{\star * *}$ & 170 & $.022^{\star * *}$ \\
\hline $921 \mathrm{~A}$ & Bowen Street Bridge & film & 168 & $\mathrm{nr}$ & 170 & $\mathrm{nr}$ \\
\hline $903 \mathrm{~A}$ & Challenge House & film & 168 & $\mathrm{nr}$ & 170 & $\mathrm{nr}$ \\
\hline $909 \mathrm{~A}$ & Shell Gully & film & 168 & $\mathrm{nr}$ & 170 & $\mathrm{nr}$ \\
\hline $904 \mathrm{~A}$ & Dalmuir House & film & 168 & $\mathrm{nr}$ & 170 & $\mathrm{nr}$ \\
\hline $900 \mathrm{~B}$ & Museum of New Zealand Site & dig. & 168 & .007 & 170 & $\star \star \star \star \star ~$ \\
\hline $900 \mathrm{~A}$ & Museum of New Zealand Site & film & 168 & $\mathrm{nr}$ & 170 & $\mathrm{nr}$ \\
\hline $911 \mathrm{~A}$ & Wellington Central Library & film & 168 & $\mathrm{nr}$ & 170 & $\mathrm{nr}$ \\
\hline $912 A$ & Wellington Airport & film & 169 & $.007^{\star \star \star}$ & 171 & $.005^{\star \star \star}$ \\
\hline $913 A$ & Church St Substation & film & 169 & $\mathrm{nr}$ & 171 & $\mathrm{nr}$ \\
\hline $941 \mathrm{~A}$ & Taranaki St Police Stn & dig. & 168 & 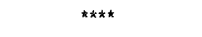 & 171 & .013 \\
\hline $918 \mathrm{~B}$ & Seismological Obsenvatory & dig. & 169 & .008 & 171 & .011 \\
\hline $916 \mathrm{~A}$ & ANZ Bank & film & 169 & $\mathrm{nr}$ & 172 & $\mathrm{nr}$ \\
\hline $914 \mathrm{~A}$ & Gray and Elliot Ltd & film & 169 & $\mathrm{nr}$ & 172 & $\mathrm{nr}$ \\
\hline $920 \mathrm{~A}$ & Wellington Hospital & film & 170 & $\mathrm{nr}$ & 172 & $\mathrm{nr}$ \\
\hline $923 \mathrm{~A}$ & Wellington Hospital & film & 170 & $\mathrm{nr}$ & 172 & $\mathrm{nr}$ \\
\hline
\end{tabular}

\footnotetext{
film film recording accelerograph

dig. digital accelerograph

sp scratch-plate acceleroscope

nr no record

* site not visited between Weber events of 19/2/90 and 13/5/90

** faulty instrument, record corrupted, or late triggering

*** component peak only, record too small to digitize

**** accelerograph not installed.
} 
WEBER EARTHQUAKE 1990 MAY 130530 UT

BAND-PASS FILTER TRANSITION BANDS ARE $0.150-0.300 \mathrm{HZ}$ AND $24.5-25.5 \mathrm{HZ}$

$\oplus$ Peak values: acceleration $3692 \mathrm{~mm} / \mathrm{s} / \mathrm{s}$, velocity $-261.4 \mathrm{~mm} / \mathrm{s}$, displacement $-61.23 \mathrm{~mm}$
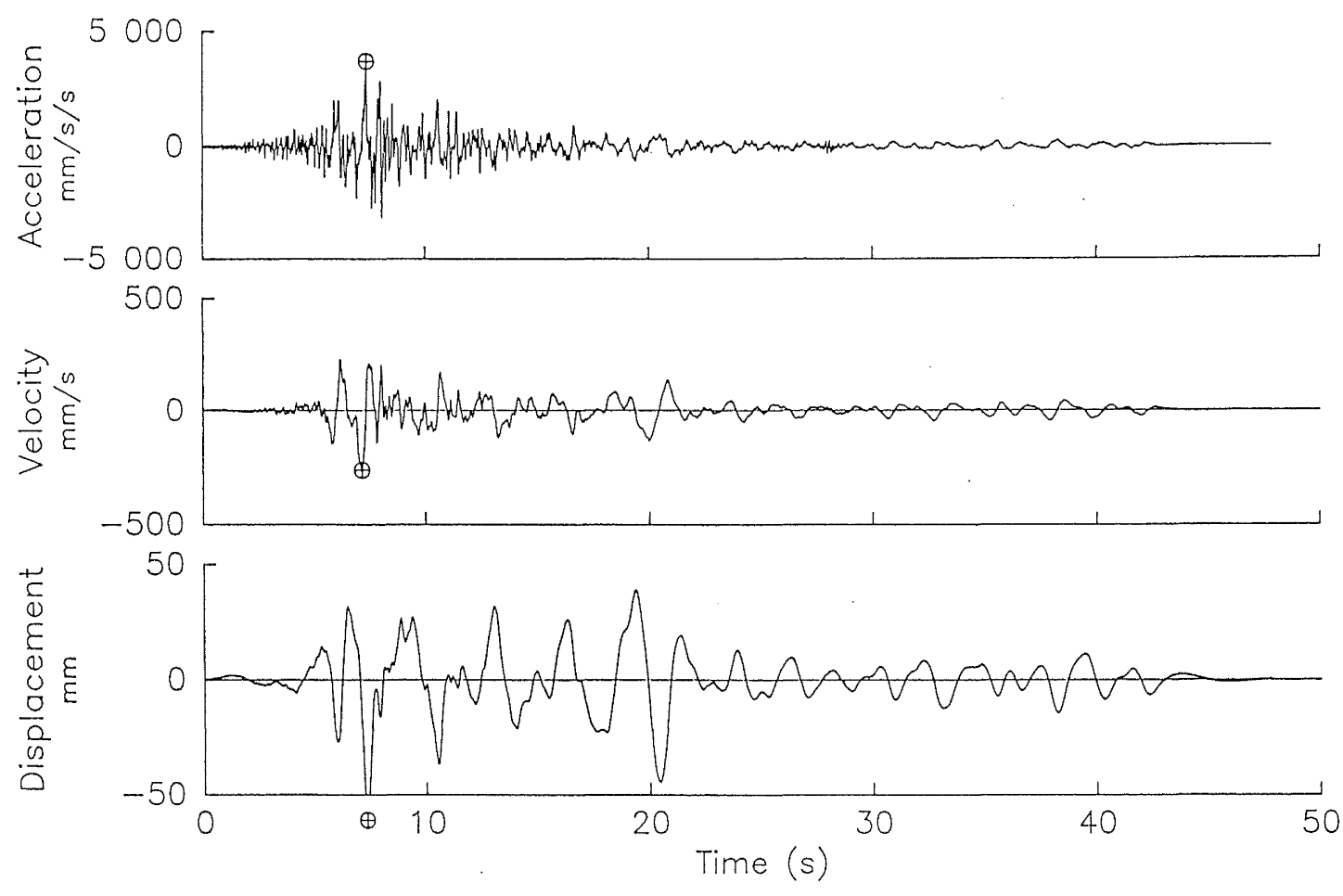

Figure 3 N67E component of the acceleration, velocity and displacement histories recorded at Dannevirke post office $25 \mathrm{~km}$ from the epicentre in the 13 May 1990 Weber earthquake.

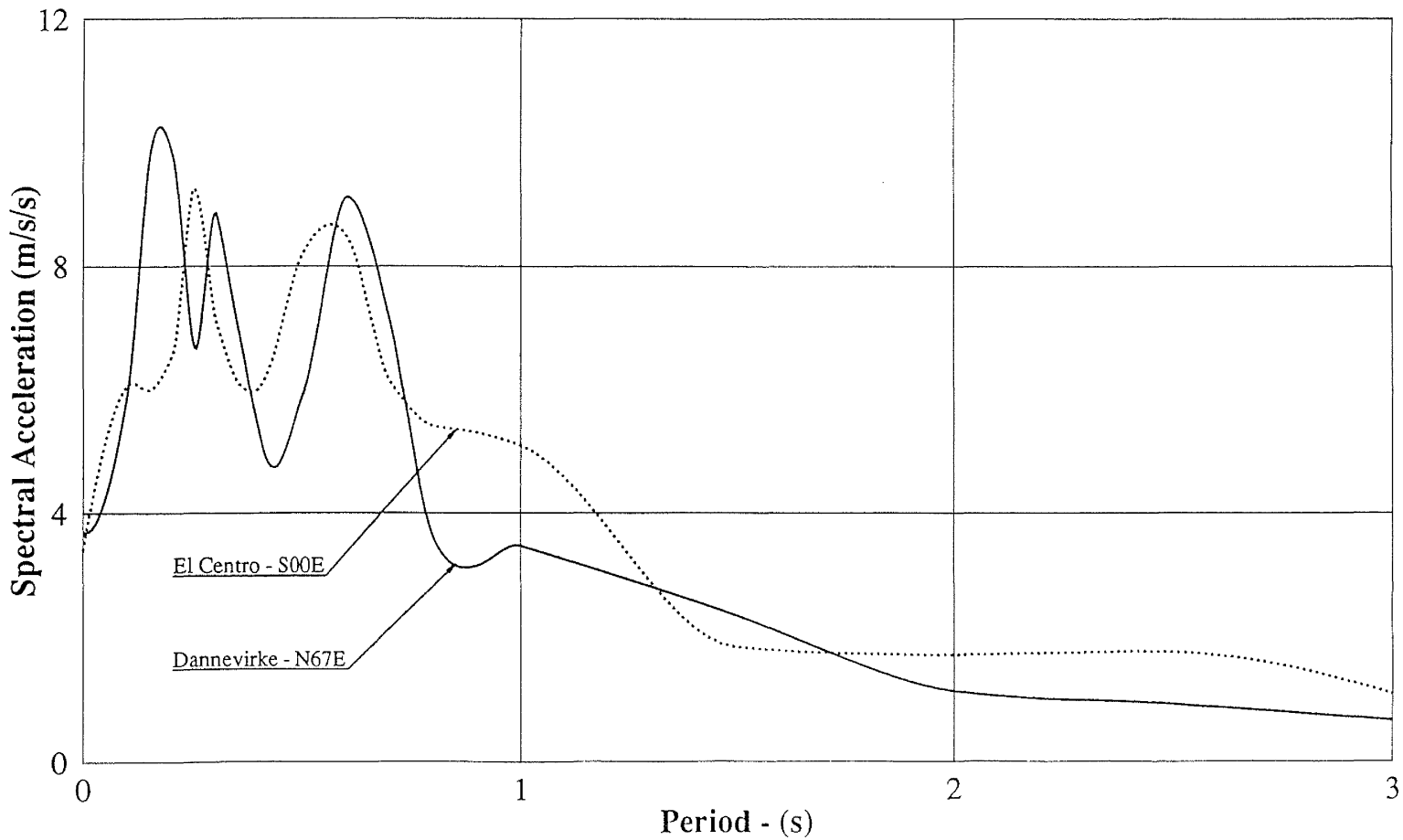

Figure 4 Comparison of the 5\% damped acceleration response spectra for the N67E component of the Dannevirke record from the 13 May 1990 Weber earthquake and the el centro 1940 north-south component. 
bridge and found it to be safe. From Waione on to Weber the slumping in the fill sections of the road became more noticeable and was similar to the damage east of Makuri.

From Weber through and past Motea, the slumping increased in frequency by about $50 \%$, but within $6 \mathrm{~km}$ of Dannevirke, there was no evidence of damage to the roads. All the roads were passable.

A bridge across the Akito River just east of Weber showed roughly $75 \mathrm{~mm}$ of slumping at each abutment, but the bridge was undamaged. It was an entirely cast insitu concrete bridge with beams monolithic with the slab, and separated from the abutment at each end with a slip joint. Evidence existed of the bridge superstructure moving with respect to the abutment but causing no real damage. The slumping would have been easily repaired by building up with asphaltic concrete.

As far as the general farmland is concerned, no signs of significant slumping were observed between Weber and Motea. Close to Weber, more ravelling of the surface of cut banks adjacent to the road was obvious, but the general countryside appeared substantially undamaged.

Along the particular route followed, there were no signs of obvious damage to manmade structures. The buildings at Pongaroa, a small township, were all in good condition and even rigid type buildings showed no distress as evidenced by their external appearance.

Water tanks associated with houses and public halls all remained on their stands and the only sign of damage seen from the road was a barge board pulled off a house by the electrical wires attached to it. There were certainly no signs of visible collapse or falling chimneys but the area is very sparsely populated.

\section{DAMAGE IN DANNEVIRKE TOWNSHIP}

Dannevirke is a fairly old town which has had very few new buildings built in the main street in the last three decades. It consists mainly of one and two storey buildings in the main street which runs roughly parallel to the ridges, or specifically, in a north east - south west orientation. Most of the buildings are unreinforced brickwork or early reinforced masonry type structures, and most brickwork buildings have lime mortar rather than cement mortar. Because of the old nature of the shops, most buildings have either boundary or party walls running at right angles to the main street, which have reasonably good shear capacity. The open nature of the frontage of the shops means that the buildings characteristically have less shear capacity in a direction parallel to the main street.

Site conditions at Dannevirke are described by Perrin [2]: "The town is on a wide alluvial terrace with cobbly gravels, sand and silt to a depth of up to 30 metres, overlying about 2000 metres of conglomerate, sandstone and mudstone of Tertiary age. The gravels are dense, and the Tertiary rocks do not cause large amplification of shaking. Basement greywacke is at a depth of about 2000 metres.

In Dannevirke, the main street was closed overnight after the earthquake to prevent looting and also to protect people from harm that might be caused by building collapses in the aftershocks. Twenty four hours after the earthquake, the road was open and the town was substantially back to normal. Two buildings were cordoned off out to the edge of the footpath to prevent access and remove danger from falling objects. One of the buildings on a side street (Davidson's Engineering) also had its frontage cordoned off. The water, power, telephone and drainage systems of the town were all working normally and did not subsequently show any damage.

A number of buildings which showed damage during the May earthquake had been damaged earlier in a smaller earthquake in February 1990.

More detailed inspections were made of the most badly damaged buildings. The descriptions that follow, are of the buildings as they appeared on Tuesday 15 May.

\section{(a) Shires Building}

This had apparently been condemned and demolition requested the previous day by the County Manager. The building housed two shops.

Demolition work began early in the morning with the roof being stripped off and the walls beginning to be knocked down.

There was little new to learn from this particular building, being a typical high, heavy, and not particularly well constructed building, built around 1910. Shear failures occurred in the brickwork as shown in Figure 5. The sarked roof no doubt prevented the front parapet falling into the street.

\section{(b) Margrethe Plaza}

This is a very large two storey complex, built possibly around 1920. It comprises three buildings, one of which is a combination of concrete floors with reinforced concrete beams and columns, and brickwork exterior walls. It has been very poorly built and there was evidence of corroding reinforcing, poor cover, and expanded mesh in part of the floor system. This building had been damaged in the February earthquake when some shop windows were apparently broken and some cracking occurred.

This building was the second most badly damaged in town, apart from the Shires Building. It had a number of shop windows broken which were in the process of being replaced at the time of inspection. The upper storey had been vacant for some time and the windows at that level, above verandah level, were also broken. A parapet collapsed (to the east in this case) falling one storey down and on through the roof of the adjacent Trustbank Building (see section (c) below).

Damage to the Margrethe Building is illustrated in Figure 6. Again, there is nothing specific to be learnt from this building because it performed fairly much as expected in a moderate to severe earthquake. An interesting factor was that the rear wall adjacent to the railway had been strengthened with vertical steel members tied at the roof level, obviously the ground level, and probably at first floor level. This wall 

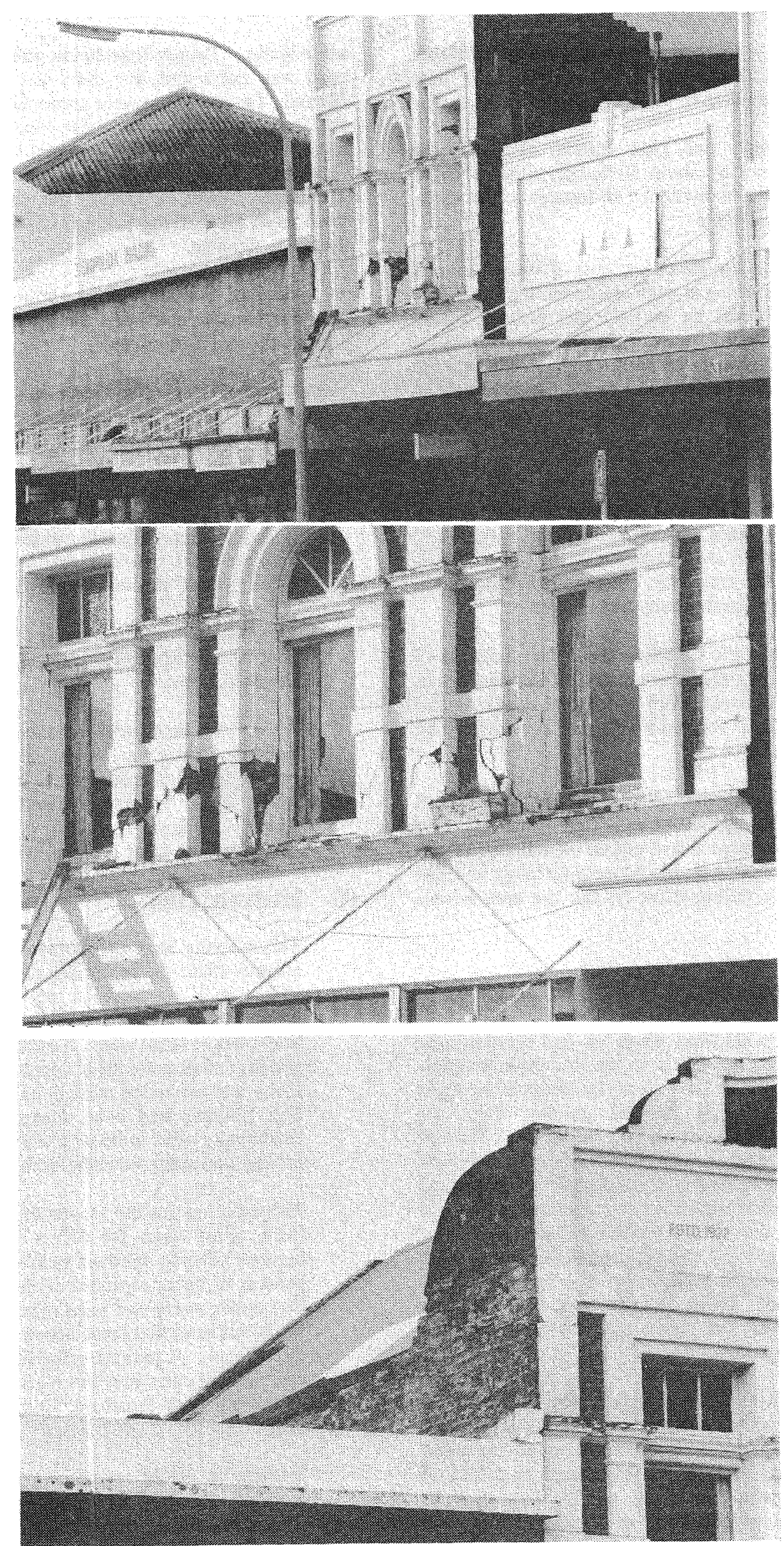

Figure 5 Damage to Shires building. 

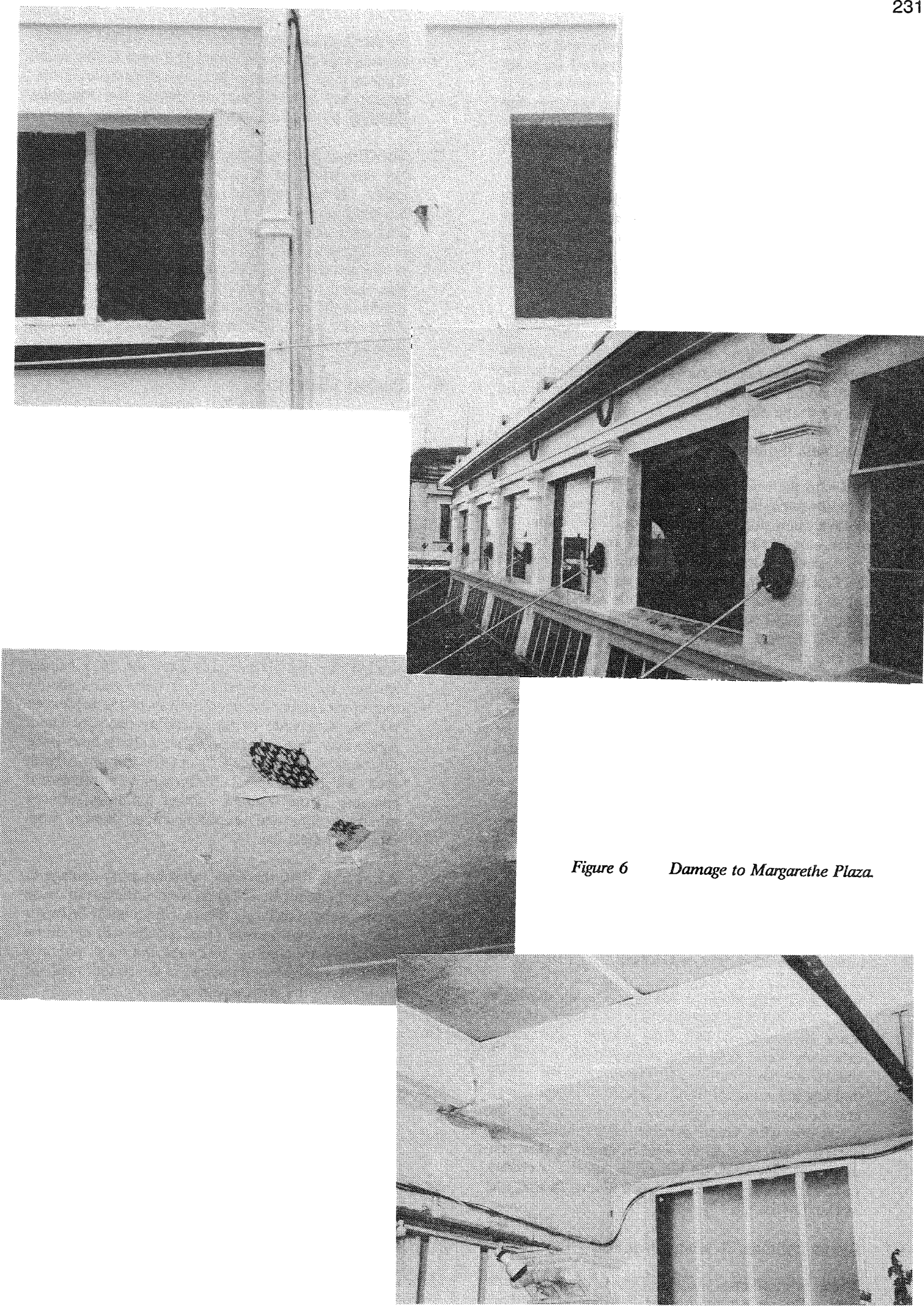
showed no signs of distress. The exterior wall on the side street (Station Street) showed typical diagonal cracking at the piers between the windows and it should be noted that this building does not have any other substantial walls running at right angles to the main road apart from that adjacent to the Trustbank Building.

The wall whose parapet collapsed into the Trustbank site had a concrete band above it, and one suspects that the direction of collapse, which did run counter to all other parapet collapses, was dictated by the roof of the Margrethe Plaza behind the parapet pushing the wall to the east.

A case study of the Margrethe Plaza was contemplated, but the building's construction, condition and general configuration ruled that a case study would have been relatively uninformative and not worth the effort.

\section{(c) Trustbank Building}

This is to the north east of the Margrethe Plaza and is totally surrounded by the Plaza complex. It is a relatively new single storey building. The parapet fell to the east of the Margrethe wall and sections of it fell completely through the corrugated iron roof of the Trustbank Building next door and on to the floor below (see Figure 7). Had anybody been below this falling brickwork, they would have been at least severely injured. The roof, which was timber frame, did a remarkable job of supporting the majority of the brickwork which fell. As parapet demolition proceeded 36 hours later, the roof was receiving most of the brickwork being knocked off and was carrying a surprisingly large load. This was pointed out to the demolition contractors who then changed their modus operandi.

\section{(d) The Cats Pyjamas Building}

This was a blue and pink painted building, two storeys high, on the corner of High Street and Ward Street which outwardly showed little sign of damage (Figure 8 ). However, close inspection showed that the Ward Street brickwork was in grave danger of collapse since there had never been any connection between the inner and outer wythes of brickwork.

Also, there was severe cracking visible on the back wall of the building, together with its annex. As with other buildings, it had lime mortar which was extremely weak, and using conventional wisdom, it should not have survived to the extent it did. The building has a timber floor at first floor level. There are the normal old fashioned tie bolts through the brickwork with large circular plates holding the parapet walls back to the roof at both the rear and the front. The roof is a full gable and it is probably sarked, as are most of the other buildings of that era in Dannevirke.

\section{(e) Gowan Building/Masonic Chambers}

These two buildings are side by side on the eastern side of the main road, not far from Shires Building.
Neither building was inspected in detail, but it could be seen that the two buildings had been hitting each other at their boundary. Some cracking beneath the central bay window was obvious in the Masonic Building, but its penetration was unknown.

The Gowan Building alongside showed some cracking but the nature of its construction system was not clear. It was reported that the owner had full drawings of this old building but he could not be contacted. Latham Andrews later reported that the building was built in 1922 and was generally of reinforced concrete; the building had no sidewalls but was butted up to the party walls. There were many cracks in the concrete, a large number of which were filled with moss. An exposed corner of a column showed reinforcing with quite large longitudinal bars.

\section{(f) Ruahine Chambers}

This was not fully inspected. It was vacant and locked having been damaged in the February earthquake. It suffered more damage and will probably be demolished. This building is only single storey with an iron roof but its strong walls (in shear) are parallel to the main road and therefore it was probably hit harder by the earthquake than were comparable buildings elsewhere in Dannevirke.

\section{(g) Other Damage}

The Municipal Chambers, a large theatre type building, was strengthened by pouring concrete bands around the top of the walls after the 1931 Napier earthquake. It is reported that there was some 15 $\mathrm{mm}$ of movement between the top of the brickwork and the underside of the overlying concrete band. Apart from that, the building appears to have been substantially undamaged except for the proscenium arch which was cracked through the reinforced concrete at the intrados. Other buildings suffered minor cracking and secondary minor damage from falling parapets etc.

Apart from that, there was no substantial damage to any of the other buildings in town sufficient to cause concern about collapse. There will probably be repair work going on for some time, but this will not all be earthquake related as, no doubt, the local authority will take a heightened interest in the condition of the buildings in the commercial area.

\section{(h) Undamaged Buildings}

It is very important to look at what did survive the earthquake and, as discussed previously, most buildings built after 1935 showed little to no sign of any damage. There are a number of heavy buildings, complete with large open spaces within them, such as the Anglican Church, the Public Trust Office, the Public Library, the Fire Station, the Westpac Bank Building, and the BNZ Building. The latter did have some damage to its brickwork, being cracking around some of the facades, but it was not serious. The interior and the roof space of the building was inspected and little damage of real concern was found. 

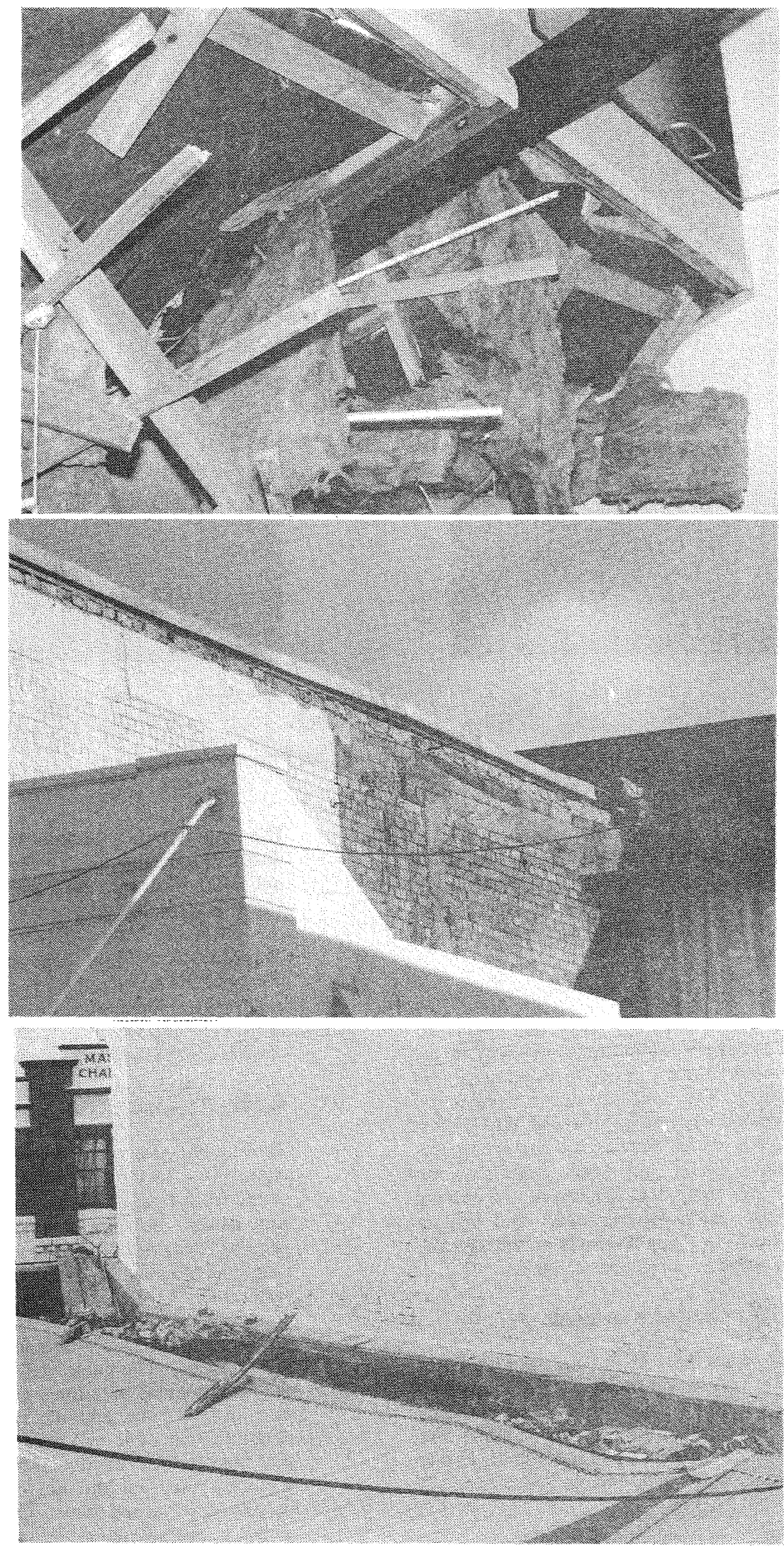

Figure 7 Damage to the Trustbank building. 

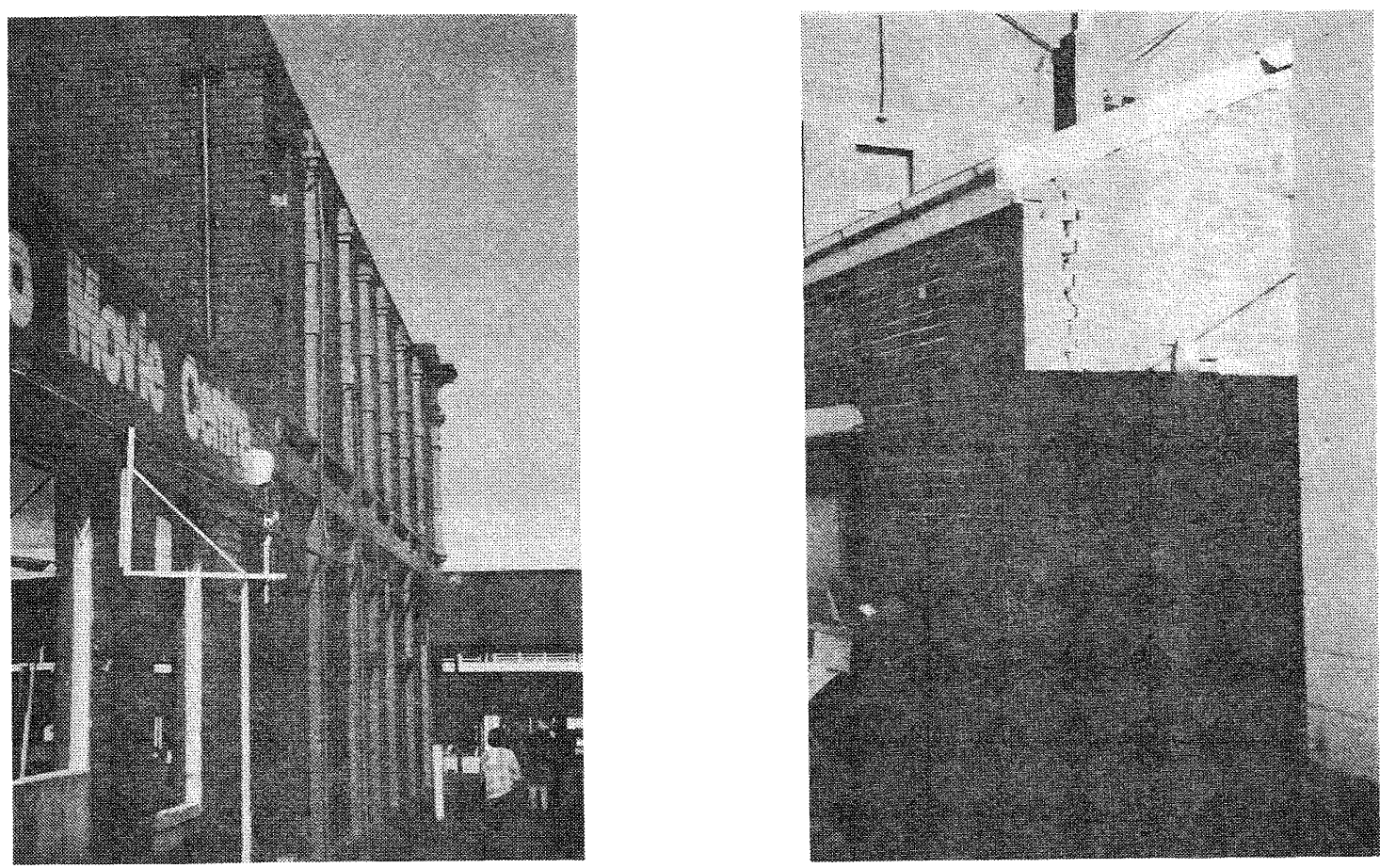

Figure 8 Damage to the Cats Pyjamas building.

\section{(i) Oringi Meatworks}

This is a new complex about $5 \mathrm{~km}$ south of Dannevirke. The Chief Engineer reported a broken water main, but nothing else was damaged. The Works was fully operational and it was decided not to inspect the site.

\section{(j) Hospital}

The hospital is mainly unreinforced masonry at the rear and a more modern concrete building at the street frontage. The hospital has a timber on concrete ground floor, and a joist and timber first floor. There was minor cracking to one area of an old brickwork building, but apart from that, no damage at all. All equipment functioned and nothing fell off shelves. Some of the larger and heavier equipment like X-ray equipment was on wheels, and that probably helped it survive undamaged.

\section{(k) New Zealand Wool Spinners Building}

This is a large industrial complex on the immediate outskirts of Dannevirke, on the road leading towards Motea. It is a large two bay portal frame building with a span of some $30 \mathrm{~m}$. The building has blockwork walls, steel frames, and not a lot of visible bracing, although it is probably no older than 15 years.

No damage occurred to the building or its adjacent offices at all. The management reported that bales of wool, which were stacked four high, were thrown about and had to be restacked.
Eye witnesses said the floor was rolling up and down during the earthquake, to the extent that they could not walk. There are no signs of damage to the floor which is a reinforced concrete slab on grade.

There are some very large spinning machines with pits beneath them and these were not thrown out of alignment. Furthermore, one machine was being reinstalled and was sitting on blocks of wood over a concrete pit. It remained unmoved.

\section{(l) Davidson's Engineering}

This is a big open warehouse type building, one storey high, with a very steep roof and a high parapet truss at the front (street) of the building (Figure 9). The roof of the building is supported by a tied rafter system, each rafter being a queen post beam. The long steel bar eaves ties which connect the queen post rafter feet, have, of course, no capacity to resist compression. The timber roof purlins frame into holes in the brickwork behind the high gable above the footpath. The gable wall was pulled away from the roof, opening up quite a gap between the roofing iron and flashing, and the roof face of the gable parapet. The gable end did not move far enough to pull the purlins ends out of their housings and therefore the roof did not collapse though it has moved at least $100 \mathrm{~mm}$. The side walls, at right angles to the side street but running parallel to the main street of Dannevirke, have severely bowed and at a rough estimate it would have moved at the top by at least $200 \mathrm{~mm}$. The building did not collapse but was in fairly unstable condition. The interior of the 


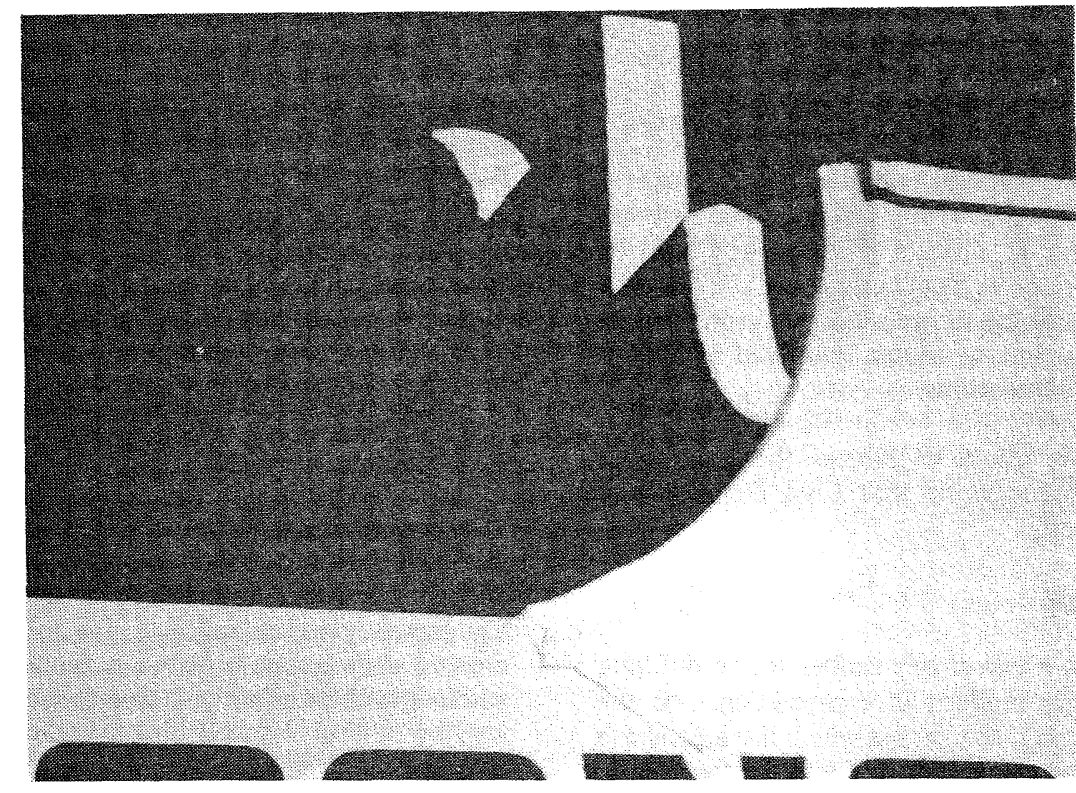

Figure 9 Damage to Davidson's Engineering building.

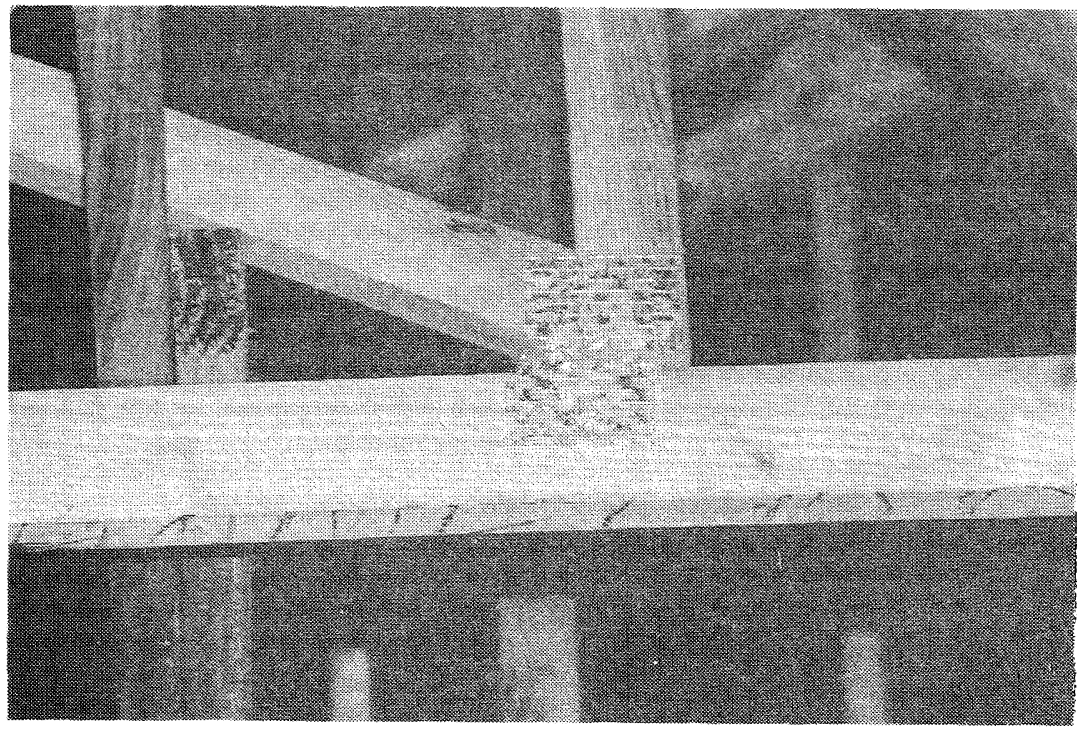

Figure 10 Regent Theatre - damage to timber truss node due to impact from masonry debris falling on the roof.

building was full of engineering equipment but the only damage was a box of drill bits which toppled and fell.

\section{(m) Other Reports}

Many buildings have been converted to uses that were different to their original purpose without the Council being aware. Generally the buildings in Dannevirke are old and many are structures which would fall within the definition of 'earthquake risk buildings', should the local authority wish to classify them.
Damage to shops' contents was less severe than one would have expected. The majority of shops lost little off their shelves and that which fell was not badly damaged.

There were no reports of damage at Waipukurau, and it was decided not to travel that far to make inspections. 


\section{DAMAGE TO RESIDENTIAL BUILDINGS}

Most of the damage to residential buildings occurred over a very small area centred around Motea. While some damage was recorded in Dannevirke, most of this consisted of brick chimneys detaching themselves from houses, and small cracks in single storey brick buildings or crease lines in scrim walls. The more extensive damage at Motea consisted of houses being shifted off their foundations.

The details that follow relate to houses that had been recognised as being damaged or that Civil Defence had earmarked for inspection.

\section{Simmons House - Motea.}

The Simmons House is a two storey timber frame building and appears to be fairly modern in construction. At the southern end of the house is the garage which has a concrete floor cast on grade. The remainder of the two storey house is tied back to this garage and it is on timber piled foundations. The house is clad in fibrolite.

Damage consisted of cracked fibrolite around windows, but the most significant damage was that the house had shifted off the centre line of the piles by nearly $150-200 \mathrm{~mm}$. Bearers were only just on the edge of the $125 \mathrm{~mm}$ diameter piles. The southern end of the house, which was tied to the garage, did not appear to have moved, and this eccentricity had accentuated movements at the furthest corners away from the garage.

This movement had resulted in extensive damage inside and to the sewer and stormwater pipes. Wood burners had been knocked over and fireplace brick facings had been pulled off their foundations. Downpipes were moved out of position and dislocated from the continuation of the pipe in the ground.

The rear yard of the house was fill material. This showed large cracks which appeared to follow the contours of the existing ground.

When the earthquake hit on Sunday, one of the young Simmons children was crawling on the backyard. The parents watched in horror from their house as cracks opened and closed around the young infant. They themselves could not move and help the child who precariously crawled back across opening and closing cracks.

\section{Duncan House - Motea}

The Duncan house comprises a colonial single storey house with a two storey garage. The lower level of the garage is in concrete block while the upper level is of stucco construction. Damage to the house was extensive below the floor level (Figure 11). The house had moved in an east to north-east direction by approx-imately $200 \mathrm{~mm}$. There were no cantilever or braced piles and the house was sitting just on ordinary piles. In the eastern corner, the progress of the house was stopped by the concrete deck area. However, when the house hit this concrete slab, it knocked out the ranch sliders. Also, at the eastern end of the house, a sunroom floor area became detached from the remaining part of the house and fell completely off the piles. Inside, there was extensive damage to the furniture. Legs to much of the antique furniture were snapped off, windows were cracked, doors and windows were all jammed, cupboards were jammed, and everything that was in cupboards was thrown on to the floor. A verandah on the western side was ripped away from the house as it moved in the easterly direction. A small changing area adjacent to the spa pool was also ripped away from the house. One of the chimneys in the house fell through this adjoining roof and broke some of the timber framing members. The new fireplace which had been replaced after the February earthquake showed less damage but still suffered cracking. The associated hot water cylinder pipes had also been flexed but not cracked.

The concrete block walls of the garage sustained quite extensive damage. The southern end of the garage was acting as a retaining wall. The dynamic earth pressures against this, plus the buffing of the building against the bank, created a discontinuity between the side and end wall. The stucco structure above remained rigid but followed the side wall by pulling out and blowing the side cover of the top block of the end wall. This top structure also disconnected itself from the joining roof to the main house.

It was difficult to check whether there was any reinforcing steel tying the two corners together. The vertical cracking pattern suggests that there was no reinforcing between these two walls. Certainly, there was no steel in the top course anchoring the bottom plate bolts into the top of the wall.

The other interesting thing to note was the water tank. At the time of the earthquake it was full to the brim with 2,500 gallons of water. The concrete tank shows a definite movement of $125 \mathrm{~mm}$ in an easterly direction.

Workers also noticed a large amount of whipping of the overhead power lines causing sparks and flashes. While some evidence was found on one other house, it did not seem to be supported by the damage reports from local energy boards.

\section{Beetham House - Waione}

The Beetham house is located in Waione which is approximately $10 \mathrm{~km}$ south of Motea. Damage to this house and others further south along State Highway 52 towards Pongoroa was minimal. The house, which was a single storey timber colonial style, had remained on its piles but had sustained damage to the chimneys, and the scrim walls showed creases at wall junctions and over doors.

An interesting thing to note regarding the Beetham house was that a small bulldozer was being serviced over a pit in the garage. After the earthquake, the bulldozer was found in the pit.

\section{Small House - Waione}

This was a modern brick veneer house. While it did not have the expected cracking patterns at the brick veneer corners, it did have one area where the brick veneer had completely fallen out and another area where a large crack had opened two thirds up the wall height from the ground. The chimney had also snapped at mid height and was cranked into the building. 

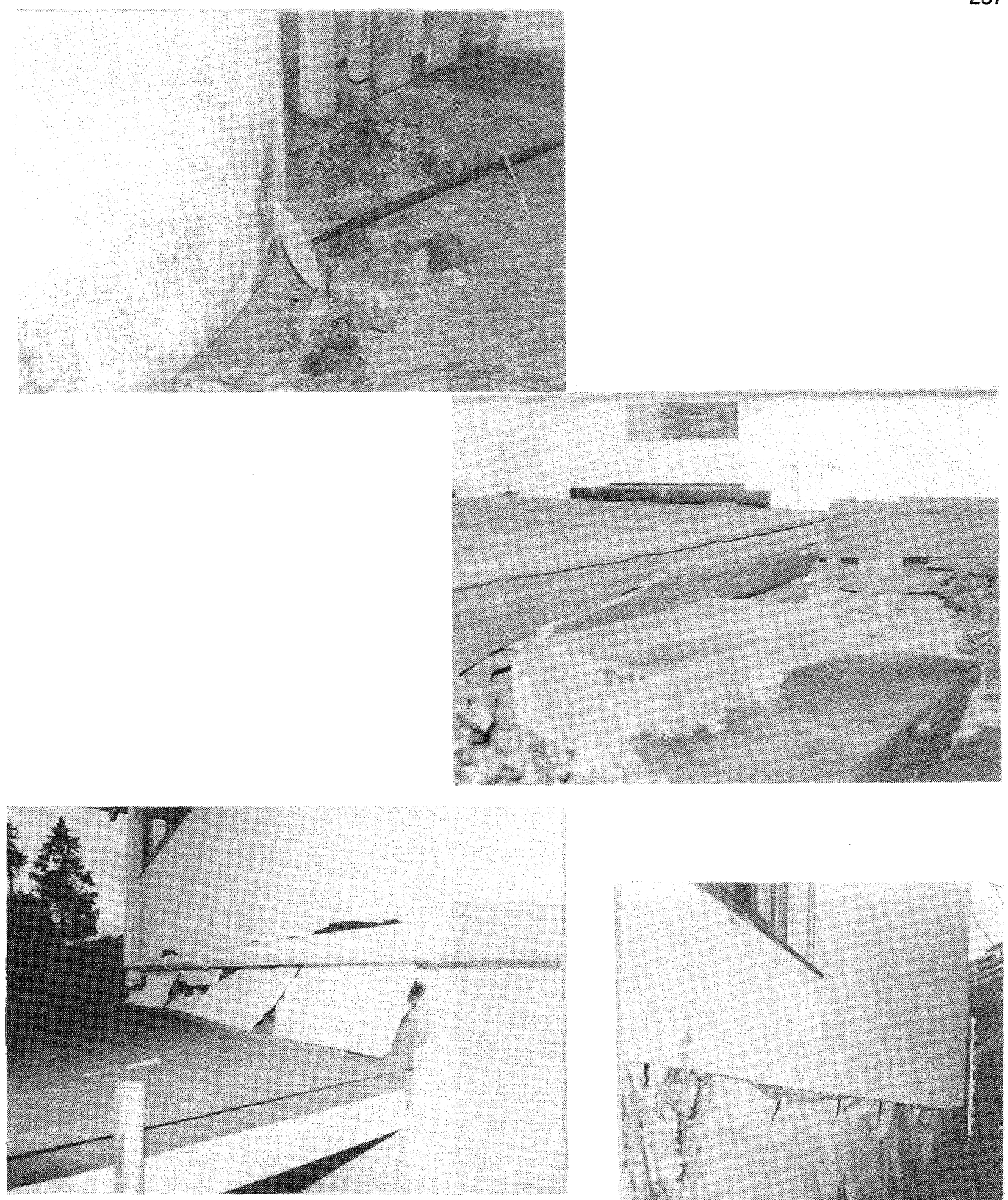

Figure 11 Damage to the Duncan house, Motea

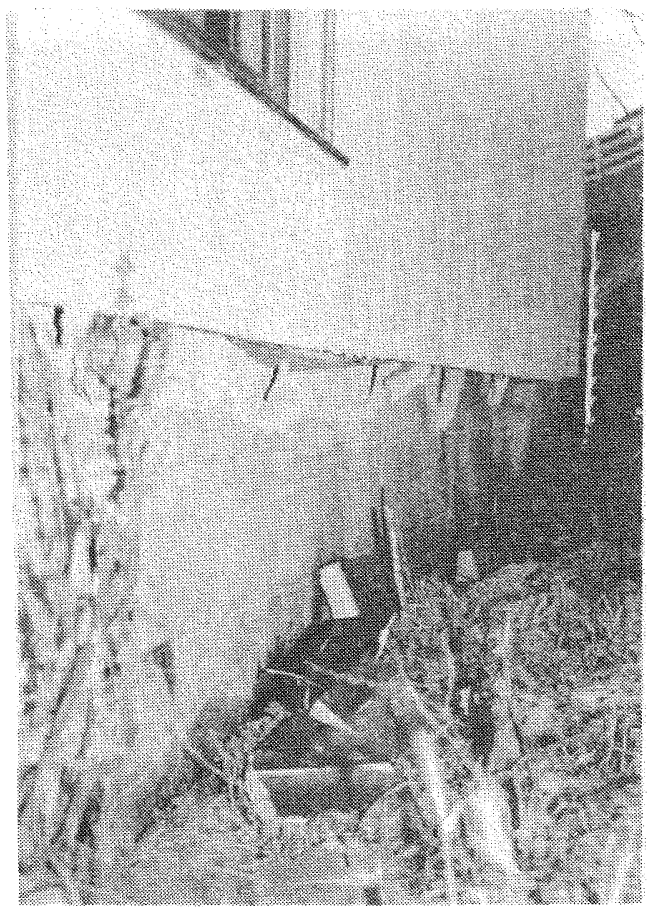



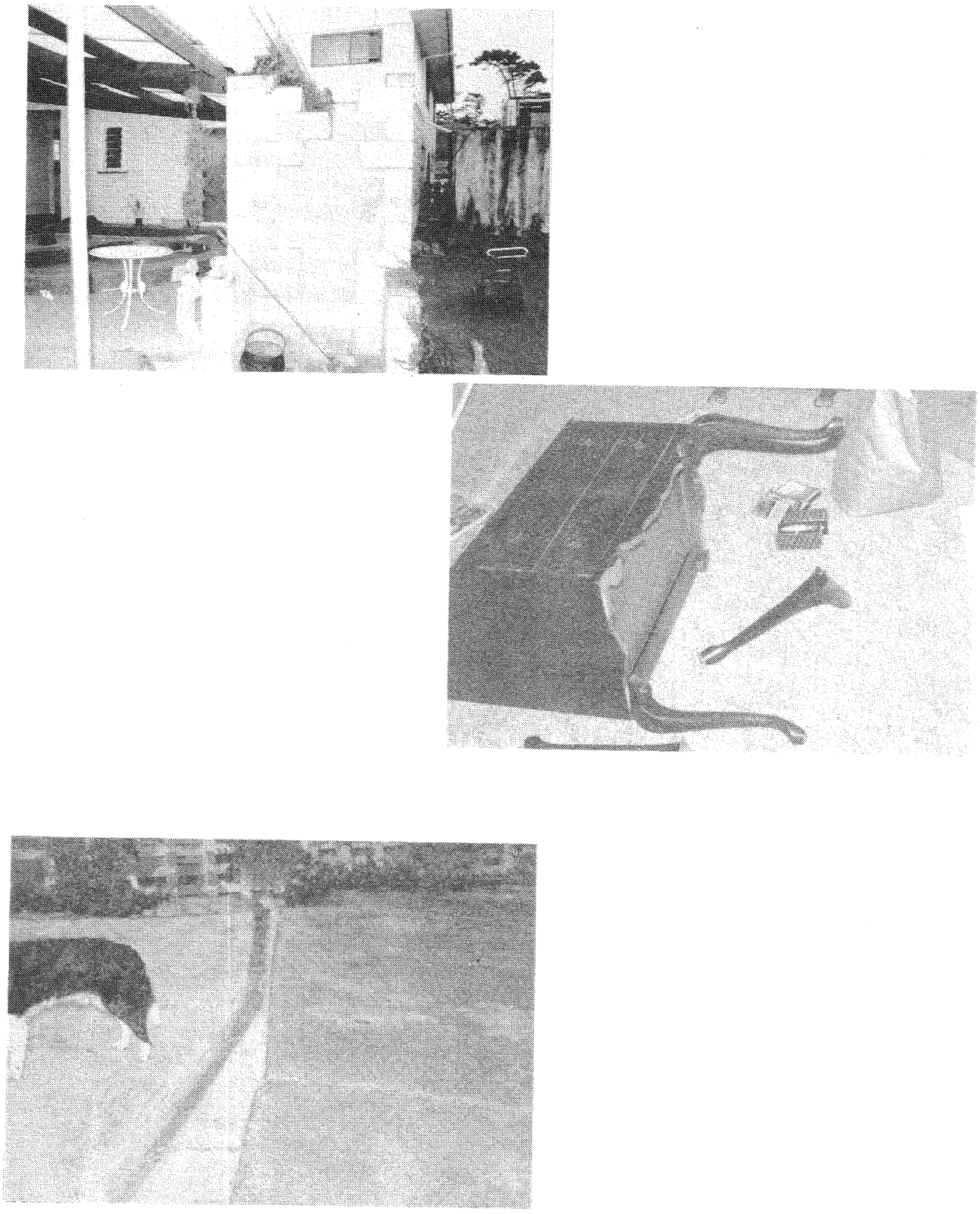

Figure 11 (cont.) Damage to the Duncan house, Motea. 


\section{ACKNOWLEDGEMENTS}

The seismological information was provided by Graeme McVerry of the Institute for Geological and Nuclear Sciences.

\section{REFERENCES}

1. Cousins, W.J., R.T. Hefford, G.H. McVerry, S.M. O'Kane and D.E. Baguley, "Computer analyses of New Zealand earthquake accelerograms", Volume 6, Reords from the Weber Earthquake of 13 May 1990, DSIR Physical Sciences, Lower Hutt, New Zealand, 1991

2. Cousins, W.J., R.T. Hefford, G.H. McVerry, S.M. O'Kane and D.E. Baguley, "Computer analyses of New Zealand earthquake accelerograms", Volume 5, Reords from the Weber Earthquake of 13 May 1990, DSIR Physical Sciences, Lower Hutt, New Zealand, 1991

3. Dowrick, D.J. and S. Sritharan, "Peak ground accelerations and attenuation in New Zealand", New Zealand National Society for Earthquake Engineering Conference, Wairakei, March 1993.

4. Dowrick, D.J. and S. Sritharan, "Attenuation of peak ground accelerations in some recent New Zealand earthquakes", submitted to the Bulletin of the New Zealand National Society for Earthquake Engineering, 1993.

5. Joyner, W.B. and D.M. Boore, "Peak horizontal acceleration and velocity from strong-motion records including records from the 1979 Imperial Valley, California, earthquake" Bulletin of the Seismological Society of America, Vol. 71, pp2011-2038, 1981.

6. Dowrick,D.J. and E.G.C. Smith, "Surface wave magnitudes of some New Zealand earthquakes 1901-1988", Bulletin of the New Zealand National Society for Earthquake Engineering, Vol. 23, No. 3, September 1990.

7. Perrin, A.T., "Dannevirke earthquake of 13 May 1990: Field inspection 14-15 May 1990", DSIR New Zealand Geological Survey Immediate Report, 21 May 1990

\section{APPENDIX}

\section{EVENTS BETWEEN THE EARTHQUAKE AND JANUARY} 1991

A discussion with Bob Smith, Tararua District Council Corporate Planning Director (former County Engineer), revealed the following:

(a) The Shires Building, which was demolished immediately after the earthquake, has since been rebuilt.

(b) The Margrethe Plaza is vacant throughout the entire top level and the rear of the building. The street frontages are still occupied by shops and the 'well', being the slot that the Trustbank Building fits into, has had the surrounding walls strengthened for the time being. Work is still proceeding to establish the best way to strengthen the building.

(c) The Cats Pyjamas Building has been demolished and is not being considered for rebuilding because of the lack of potential tenants.

(d) The Leader \& Watts Building on the north eastern side of the Cats Pyjamas Building, has been demolished and will be rebuilt.

Apparently this building was assessed to see if it could be demolished down to one storey only but there was insufficient strength in the remaining structure.

(e) The Gowan Building has had the cracks repaired with epoxy injection, as has the Masonic Building alongside. These were the two buildings which were hitting together.

(f) Davidsons Building is vacant and is yet to be demolished.

(g) A two storey brick building north east of the Acropolis Restaurant, which was not inspected on the reconnaissance, has been demolished.

(h) The Municipal Theatre has had the movement between the brickwork wall and the overlying concrete band epoxy mortared and some steel brackets put in the corners of the long walls. A crack in the proscenium arch has been strengthened by putting a steel frame behind it. 